\title{
Aplikasi Tes Buta Warna dengan Metode Ishihara Metode Colour Gradation dan Metode Farnsworth
}

\author{
Riski Ardiyan ${ }^{\# 1}$, Helfi Nasution ${ }^{\# 2}$, Tursina ${ }^{\# 3}$ \\ \#Program Studi Informatika Universitas Tanjungpura \\ Jl. Prof. Dr. H.Hadari Nawawi, Pontianak, Kalimantan Barat, 78115 \\ ${ }^{1}$ riskikibon@gmail.com \\ ${ }^{2}$ helfinaseinformatika.untan.ac.id \\ ${ }^{3}$ tursinalinformatika.untan.ac.id
}

\begin{abstract}
Abstrak - Pada umumnya istilah dimana seseorang mengalami kesulitan untuk membedakan warna lebih dikenal dengan istilah buta warna. Berdasarkan sifatnya, buta warna dapat dibedakan menjadi dua yaitu yang bersifat kongenital (berasal dari turunan orang tua) dan yang bersifat akuisita (didapatkan ketika dalam pertumbuhan). Pengembangan aplikasi diagnosa buta warna dengan bertujuan untuk mempermudah dalam tes buta warna dan memperkecil potensi menghapal pola yang dilakukan oleh peserta tes buta warna. Aplikasi ini menggunakan metode heuristic ganda yaitu metode ishihara, metode colour gradation dan metode farnsworth.

Hasil dari penelitian ini adalah aplikasi diagnosa buta warna dengan yang dikembangkan menggunakan bahasa pemrograman Visual Basic 6 dan telah diuji serta mendapatkan rekomendasi oleh dokter spesialis mata.
\end{abstract}

Kata kunci - Buta Warna, Colour Blindness, Metode Ishihara, Metode Colour Gradation, Metode Farnsworth

\section{Pendahuluan}

Buta warna adalah kekurangan penglihatan atas warna. Mata tidak akan melihat warna seperti biasanya jika ada masalah dengan pigmen pada reseptor warna. Jika salah satu pigmen hilang, maka mata akan memiliki masalah melihat warna tertentu. Penderita buta warna bisa kesulitan melihat warna merah, hijau, biru, atau campuran warna-warna ini. Pada kondisi penderita buta warna total, tidak ada warna yang dapat dilihat sama sekali namun hal ini sangat jarang terjadi.[1]

Pada umumnya proses tes buta warna dilakukan secara manual, yaitu dengan memperlihatkan lembaran demi lembaran gambar yang terdapat pada buku tes buta warna dan peserta tes diminta menyebutkan angka-angka yang terlihat pada gambar. Dari jawaban yang diberikan oleh peserta tes buta warna, dapat disimpulkan apakah peserta tes tersebut mengalami buta warna total, buta warna parsial atau normal.
Media yang digunakan selama ini adalah berupa plat dari buku atau kertas yang sewaktu - waktu dapat rusak bahkan berubah warna seperti memudar atau sobek pada kertas soal tersebut. Hal inilah yang menjadi latarbelakang terciptanya inovasi untuk mengembangkan sebuah aplikasi diagnosa dini buta warna dengan metode ishihara, metode colour gradation dan metode farnsworth.

\section{TINJAUAN PUSTAKA}

Buta warna merupakan kelainan genetik atau bawaan yang dapat diturunkan dari orang tua kepada anaknya, buta warna juga dapat terjadi ketika seseorang mengkonsumsi obat-obatan dalam jangka waktu tertentu karena menderita sebuah penyakit. Penglihatan warna sangat berpengaruh terhadap kehidupan seseorang, karena dapat menimbulkan masalah dalam menentukan warna. Umumnya penderita buta warna tidak dapat membedakan warna merah, hijau, kuning, biru maupun warna-warna gradasi. [2]

Penderita buta warna mungkin hanya bisa melihat beberapa gradasi warna, sementara sebagian besar orang dapat melihat ratusan warna. Sebagai contoh, ada penderita buta warna tidak dapat membedakan antara warna merah dan hijau, namun bisa melihat warna biru dan kuning dengan mudah. Beberapa orang bahkan tidak menyadari bahwa dirinya mengalami buta warna hingga mereka menjalani tes penglihatan warna.[2]

Menurut (Guyton \& Hall, 1997) Metode Ishihara yaitu metode yang dapat dipakai untuk menentukan dengan cepat suatu gejala kelainan buta warna yang didasarkan pada penggunaan pelat bertitik-titik,. Pelat ini disusun dengan menyatukan titik-titik yang mempunyai bermacam-macam warna. [3]

Secara umum buta warna terbagi menjadi dua yaitu buta warna total dan buta warna parsial. Buta warna total hanya dapat melihat warna hitam, putih dan abu-abu, sedangkan buta 
warna parsial tidak bisa membedakan warna-warna tertentu seperti hijau, kuning, merah dan biru. (Handayani, 2011) dalam jurnalnya yang berjudul "Gambaran Pengetahuan Mahasiswa/i Fakultas Kedokteran Universitas Sumatera Utara Stambuk 2008 - 2010 Mengenai Buta Warna" menyatakan buta warna dapat dibedakan menjadi 3 jenis, yaitu anomalous trichromacy, dichromacy dan monochromacy.[4]

Jenis buta warna yang tidak bisa membedakan seluruh warna alias hanya bisa melihat hitam putih saja disebut juga buta warna total. Selain itu, masih ada dua jenis buta warna lainnya, yaitu buta warna merah-hijau dan buta warna birukuning.[5]

Jenis buta warna dapat dikategorikan menjadi 2 kategori yaitu buta warna parsial dan buta warna total, berikut beberapa keadaan dimana fungsi reseptor mata berkurang.[5]

Anomalous trichromacy adalah gangguan penglihatan warna yang dapat disebabkan oleh faktor keturunan atau kerusakan pada mata setelah dewasa. Penderita anomalous trichromacy memiliki tiga sel kerucut yang lengkap, namun terjadi kerusakan mekanisme sensitivitas terhadap salah satu dari tiga sel reseptor warna tersebut.[6]

Dichromacy adalah jenis buta warna di mana salah satu dari tiga sel kerucut tidak ada atau tidak berfungsi. Akibat dari disfungsi salah satu sel pigmen pada kerucut, seseorang yang menderita dikromasi akan mengalami gangguan penglihatan terhadap warna-warna tertentu.[6]

Monochromacy atau akromatopsia adalah keadaan dimana seseorang hanya memiliki sebuah pigmen cones atau tidak berfungsinya semua sel cones. Pasien hanya mempunyai satu pigmen kerucut (monokromat rod atau batang). Pada monokromat kerucut hanya dapat membedakan warna dalam arti intensitasnya saja.[7]
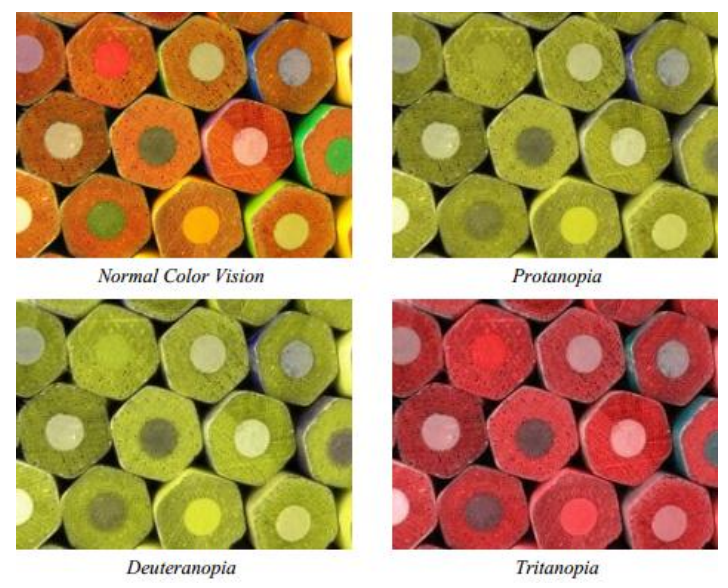

Gambar 1. Simulasi Warna pada Penderita Buta Warna

Ada beberapa penyebab seseorang mengalami buta warna, diantaranya adalah:

1) Penyakit : Terdapat sejumlah penyakit yang bisa menyebabkan buta warna, seperti penyakit parkinson, penyakit alzheimer, glaukoma, neuritis optik, leukemia, diabetes, pecandu alkohol kronis, macular degeneration, dan anemia sel sabit.

2) Usia : Kemampuan seseorang untuk membedakan warna perlahan-lahan akan berkurang seiring bertambahnya usia. Ini adalah hal yang alami dalam proses penuaan dan tidak perlu dicemaskan secara berlebihan.

3) Faktor genetika : Kebanyakan penderita buta warna mengalaminya sejak lahir dan merupakan faktor genetika yang diturunkan oleh orang tua. Penderita buta warna akibat faktor genetika jauh lebih sering terjadi pada pria dibandingkan wanita.

4) Bahan kimia : Seseorang bisa mengalami buta warna jika terpapar bahan kimia beracun misalnya di tempat kerja, seperti karbon disulfida dan pupuk.

5) Efek samping pengobatan tertentu : Beberapa pengobatan berpotensi menyebabkan buta warna, seperti digoxin, pheytoin, chloroquine dan sildenafil yang juga dikenal sebagai Viagra. Jika gangguan disebabkan oleh pengobatan, biasanya pandangan akan kembali normal setelah berhenti mengkonsumsi obat.[8]

Beberapa orang tidak menyadari bahwa dirinya menderita buta warna. Hal itu dikarenakan mereka telah beradaptasi dengan keadaan. Misalnya, karena mereka tahu bahwa warna daun itu hijau, maka berpikir dan menganggap bahwa warna hijau adalah warna yang dilihatnya. Maka dari itu, melakukan pemeriksaan buta warna dirasa perlu. Selain untuk mengetahui kondisi kesehatan mata, hasil pemeriksaan juga menjadi salah satu syarat untuk pekerjaan yang menuntut kejelian mata dalam melihat warna, seperti pilot, masinis, dan dokter.[9]

Penelitian lain telah dilakukan oleh Murti dan Santi (2011) dalam penelitiannya yang berjudul Aplikasi Pendiagnosa Kebutaan Warna dengan Menggunakan Pemrograman Borland Delphi. Penelitian ini menghasilkan alat bantu tes pemeriksaan gangguan penglihatan terhadap warna, karena dari rancangan sistem pakar kebutaan warna memberikan soal pemeriksaan yang sama seperti pemeriksaan secara manual dengan buku / alat tes Ishihara yang dilakukan oleh seorang dokter mata.[10]

Penelitian terdahulu yang relevan merupakan hal yang cukup penting untuk dijadikan data pendukung dalam melaksanakan penelitian karena didalamnya terdapat acuan yang merupakan teori atau hasil dari berbagai penelitian. Penelitian terdahulu mengenai tes buta warna telah dilakukan oleh Ratri Widianingsih (2010) dalam penelitiannya yang berjudul Aplikasi Tes Buta Warna dengan Metode Ishihara Berbasis Komputer. Dalam penelitian ini menghasilkan suatu aplikasi tes buta warna berbasis komputer yang digunakan untuk tes buta warna di POLTABES Samarinda. Dengan hasil keluaran berupa hasil cetak Surat Keterangan Kesehatan dengan menyebutkan hasil tes buta warna yaitu normal, buta warna parsial atau buta warna total.[11]

Aplikasi yang dibangun menggunakan software Delphi7 yang akan menampilkan soal dan hasil penilaian pasien yang sudah diolah menjadi sebuah bentuk yang berarti bagi 
pengguna, yang bermanfaat dalam pengambilan keputusan mengenai penilaian kesehatan mata pasien.[12]

Delphi merupakan suatu aplikasi bahasa pemrograman yang memberikan berbagai fasilitas pembuatan aplikasi visual. Embarcadero Technology selaku pengembang produk compiler Delphi semakin mengembangkan produknya yang dinamai Delphi sehingga memudahkan programmer dalam membuat suatu aplikasi atau sistem. [13]

Delphi adalah suatu bahasa pemrograman yang menggunakan visualisasi sama seperti bahasa pemrograman Visual Basic (VB). Namun Delphi menggunakan bahasa yang hampir sama dengan pascal (sering disebut objek pascal), sehingga lebih mudah untuk digunakan. Bahasa pemrograman Delphi dikembangkan oleh Code Gear sebagai divisi pengembangan perangkat lunak milik Embarcadero. Divisi tersebut awalnya milik Borland, sehingga bahasa ini memiliki versi Borland Delphi. Delphi juga menggunakan konsep yang berorientasi objek (OOP), maksudnya pemrograman dengan membantu sebuah aplikasi yang mendekati keadaan dunia yang sesungguhnya. Hal itu bisa dilakukan dengan cara mendesign objek untuk menyelesaikan masalah. [14]

Hasil tes seorang pasien merupakan privasi yang dimiliki antara pasien dan dokter, oleh karena itu sistem ini dibangun berbasis desktop. [15]

Aplikasi yang dibangun setelah dikonsultasikan kepada ahli pakar yaitu adalah dr. Mahyudi, Sp.M., M.Kes maka akan diujikan. Pengujian yang akan digunakan adalah pengujian blackbox adalah pengujian yang dilakukan dengan mengamati hasil eksekusi melalui data uji dan memeriksa fungsional dari perangkat lunak. Jadi dianalogikan seperti kita melihat suatu kotak hitam, kita hanya bisa melihat penampilan luarnya, tanpa tahu ada apa dibalik bungkus hitamnya. Sama seperti pengujian blackbox, mengevaluasi hanya dari tampilan luarnya, sedangkan metodenya telah baku di dunia kedokteran serta soal - soal yang akan diujikan telah dikonsultasikan kepada dokter selaku ahli pakar dalam dunia kedokteran mata.[16]

Aplikasi buta warna yang dibangun merupakan aplikasi yang dapat menampilkan soal - soal tes buta warna dengan metode Ishihara, metode Colour Gradation dan metode Farnsworth setelah disuguhkan soal pasien diharuskan menjawab dan kemudian data jawaban pasien akan dihitung dan ditentukan hasil keputusan penilaian terhadap kesehatan menglihatan warna pasien sistem pendukung keputusan didefinisikan sebagai interaktif berbasis komputer yang membantu pengambilan suatu keputusan memanfaatkan data dan model untuk menyelesaikan masalah dalam penilaian. [17].

\section{METODOLOGI PENELITIAN}

Penelitian ini melalui beberapa tahapan seperti analisis literatur, perancangan desain dan database aplikasi, pembuatan aplikasi serta uji coba. Analisis literatur meliputi studi pustaka dan referensi mengenai buta warna, penyebab buta warna serta gejala dan akibat yang ditimbulkan akibat buta warna. Selanjutnya dilakukan perancangan aplikasi yang akan dibuat pada aplikasi meliputi keseluruhan fungsi tombol dan tata letaknya. Setelah itu dilakukan perancangan database untuk menyimpan data hasil diagnosa menggunakan aplikasi tersebut juga menggunakan repository data. Setelah selesai dibuat, aplikasi diuji untuk menganalisa apakah sudah sesuai dengan metode yang digunakan.

Spesifikasi kebutuhan adalah kondisi, kriteria atau syarat yang harus dimiliki untuk memenuhi apa yang diinginkan pengguna. Spesifikasi yang dibutuhkan dari aplikasi tes buta berikut pada tabel 1 :

TABEL I.

\section{SPESIFIKASI KEBUTUHAN}

\begin{tabular}{|c|l|c|}
\hline No & \multicolumn{1}{|c|}{ Spesifikasi kebutuhan } & $\begin{array}{c}\text { Aktor Yang } \\
\text { terlibat }\end{array}$ \\
\hline 1 & $\begin{array}{l}\text { Aplikasi Mampu memvalidasi admin untuk } \\
\text { menjaga kerahasaiaan data pasien. }\end{array}$ & $\begin{array}{c}\text { Operator / } \\
\text { Dokter }\end{array}$ \\
\hline 2 & $\begin{array}{l}\text { Aplikasi mampu melakukan serangkaian tes } \\
\text { buta warna dengan metode Ishihara. }\end{array}$ & Pasien \\
\hline 3 & $\begin{array}{l}\text { Aplikasi mampu melakukan serangkaian tes } \\
\text { buta warna dengan metode Colour } \\
\text { gradation. }\end{array}$ & Pasien \\
\hline 4 & $\begin{array}{l}\text { Aplikasi mampu melakukan serangkaian tes } \\
\text { buta warna dengan metode Farnsworth. }\end{array}$ & Pasien \\
\hline 5 & $\begin{array}{l}\text { Aplikasi Mampu menghitung skor ketepatan } \\
\text { jawaban pasien. }\end{array}$ & $\begin{array}{c}\text { Operator / } \\
\text { Dokter / } \\
\text { Pasien }\end{array}$ \\
\hline 6 & $\begin{array}{l}\text { Tersedianya Manajemen data pasien dalam } \\
\text { aplikasi. }\end{array}$ & $\begin{array}{c}\text { Operator / } \\
\text { Dokter }\end{array}$ \\
\hline
\end{tabular}

Pola arsitektur sistem yang digunakan untuk membangun aplikasi ini yaitu data terpusat, berikut arsitektur yang dihasilkan :

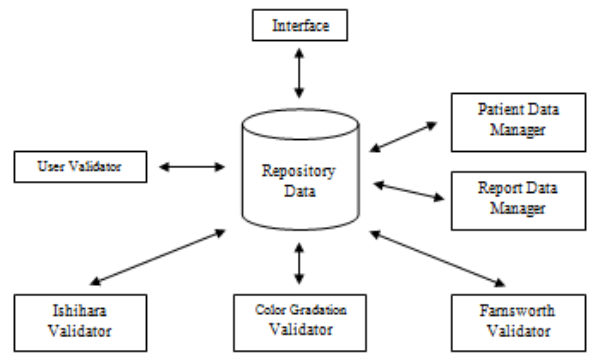

Gambar 2. Arsitektur Sistem

Penjelasan komponen pada gambar 1 yaitu :

1) User validator : adalah komponen yang bertugas untuk memvalidasi user yang login ke aplikasi. User validator terhubung dengan repository data yang menyimpan data operator / dokter yang kemudian digunakan pada proses validasi untuk menampilkan data yang dibutuhkan oleh komponen internal.[18]

2) Interface : adalah komponen yang bertugas untuk menampilkan interface kepada pengguna, setiap komponen memiliki user interface dalam pengoperasiannya. 
3) Repository : data adalah sebuah komponen basis data yang bertugas menyimpan data seluruh komponen pada sistem.[11]

4) Ishihara validator: adalah komponen yang bertugas untuk menguji buta warna dengan cara menampilkan pelat gambar Ishihara pada komponen interface serta dapat menghitung skor hasil pengujian tersebut, dan kemudian data hasil perhitungan disimpan pada repository data.[18]

5) Colour gradation validator : adalah komponen yang bertugas untuk menguji buta warna dengan cara menampilkan pelat gambar colour gradation pada komponen interface serta dapat menghitung skor hasil pengujian tersebut, dan kemudian data hasil perhitungan disimpan pada repository data.[19]

6) Farnsworth validator : adalah komponen yang bertugas untuk menguji buta warna dengan cara menampilkan pelat gambar Farnsworth pada komponen interface, serta dapat menghitung skor hasil pengujian tersebut, dan kemudian data hasil perhitungan disimpan pada repository data.

7) Patient data manager : adalah komponen yang bertugas untuk manajemen data pasien / pasien tes buta warna yang telah tersimpan pada repository data.

8) Report data manager : adalah komponen yang bertugas untuk mencetak data pasien / pasien tes buta warna yang telah tersimpan pada repository data.[20]

\section{HASIL DAN ANALISIS}

A. User Interface

Antarrmuka atau interface adalah sebuah mekanisme komunikasi antara pengguna aplikasi dengan sistem.

1) Menu Login

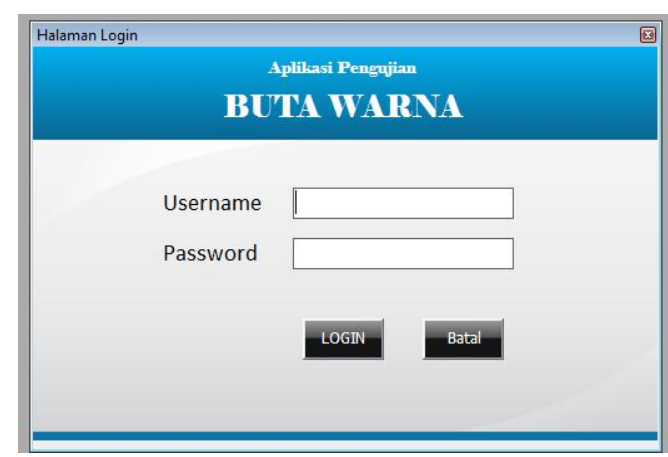

Gambar 3. Menu Login

Pada Gambar 3 menunjukkan halaman login yang berfungsi sebagai halaman autentikasi atau validasi, sehingga tidak sembarang orang yang dapat menggunakan aplikasi ini.

\section{2) Мепu Utama}

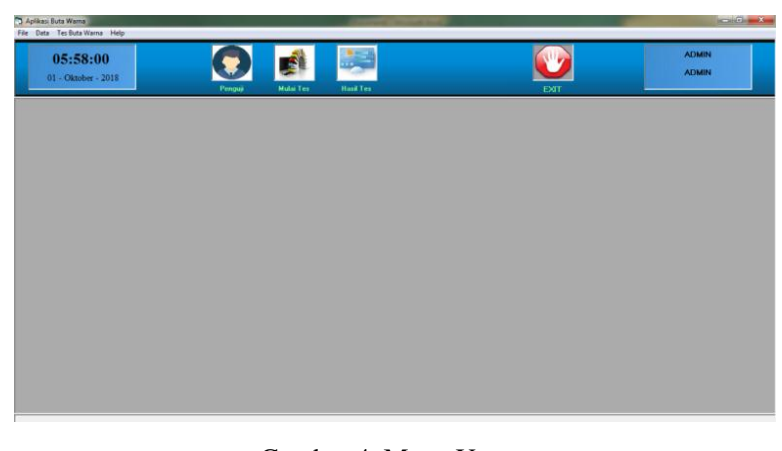

Gambar 4. Menu Utama

Pada gambar 4 menunjukkan menu utama yang berfungsi sebagai halaman utama. Pada halaman ini user dapat memilih jenis tes sesuai dengan kebutuhannya. Apakah akan melakukan pengujian dengan metode ishihara, metode farnsworth atau dengan metode colour gradation.

\section{3) Menu Tes Ishihara}

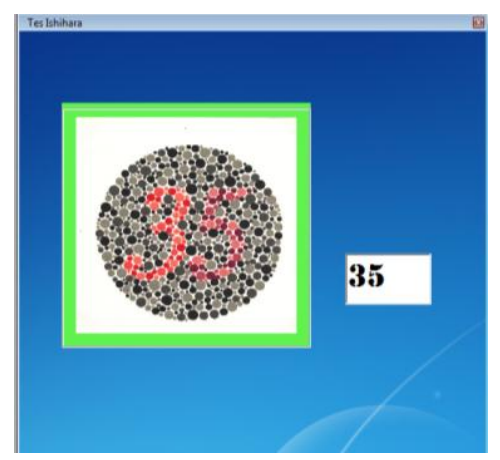

Gambar 5. Menu Tes Ishihara

Pada Gambar 5 menunjukkan menu tes ishihara yang merupakan pengujian tahap pertama. menu ini menggunakan 26 pelat dalam tes yang akan menampilkan 10 pelat warna ishihara secara acak.

\section{4) Menu Tes Colour gradation}

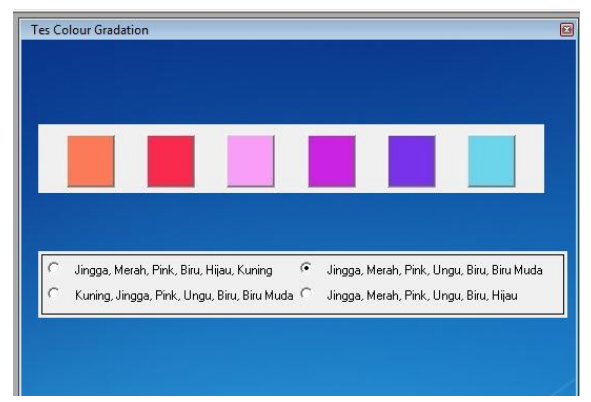

Gambar 6. Menu Tes Colour gradation

Pada gambar 6 menunjukkan menu tes colour gradation yang merupakan pengujian tahap kedua. Menu ini menggunakan 10 pelat dalam tes yang akan menampilkan 6 pelat warna gradasi secara acak. 
5) Menu Tes Farnsworth

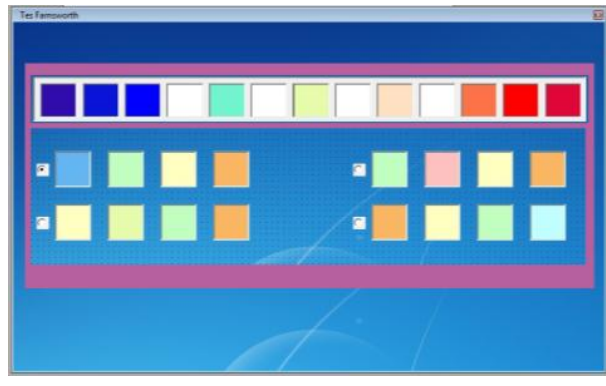

Gambar 7. Menu Tes Farnsworth

Pada gambar 7. menunjukkan menunjukkan menu tes farnsworth yang merupakan pengujian tahap ketiga. Menu ini menggunakan 12 pelat dalam tes yang akan menampilkan 8 pelat gradasi warna secara acak.

\section{6) Menu Peserta Tes}

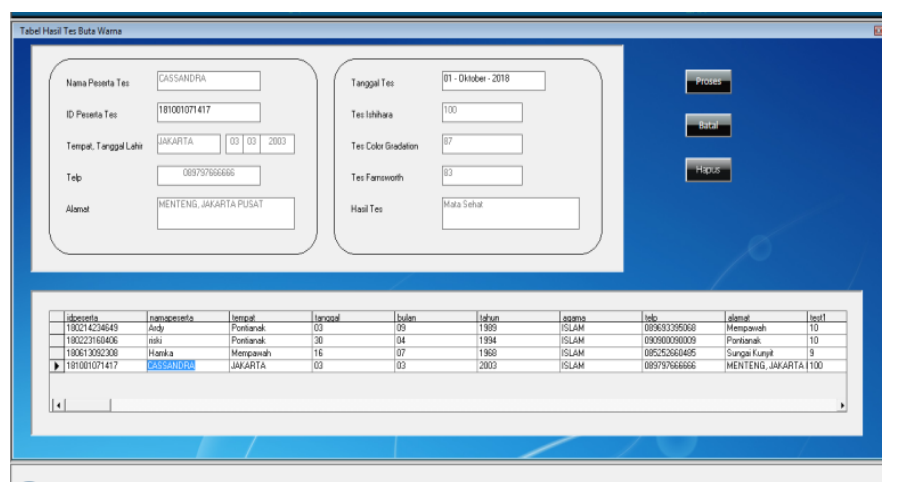

Gambar 8. Peserta Tes

Pada gambar 8. menunjukkan halaman pasien buta warna. Pada halaman ini menunjukkan biodata, skor masing - masing tes hingga skor akhir sesuai dengan pembobotan tes buta warna.

\section{B. Pengujian Aplikasi}

Dalam menggunakan aplikasi ini, ada beberapa metode yang harus dilakukan pengujian. Tahapan pengujian yang harus dilakukan adalah sebagai berikut:

1) Metode Ishihara : Pengujian menggunakan metode Ishihara dilakukan dengan cara menguji apakah peserta tes dapat mengenali perbedaan warna yang terdapat pada berbagai pelat gambar Ishihara yang berupa angka. Pelat Ishihara yang digunakan berjumlah 21 buah dengan kombinasi angka dan warna yang berbeda-beda.

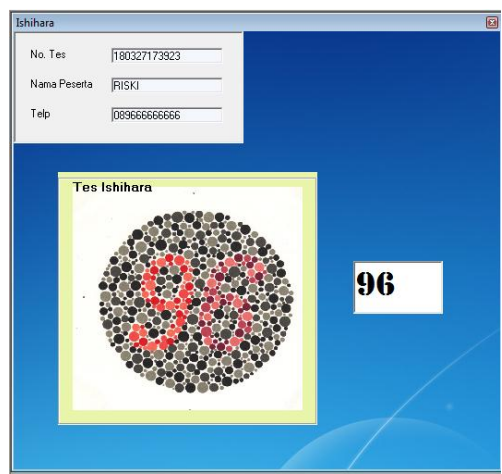

Gambar 9. Pengujian Metode Ishihara

Pada gambar 9 dapat dilihat metode ishihara yang digunakan pada aplikasi. Peserta tes akan melihat gambar angka yang terdiri dari beberapa kombinasi titik berwarna. Kombinasi titik berwarna inilah yang dijadikan salah satu filter pengujian dalam metode ishihara. Hal tersebut karena peserta yang mengalami gejala kepekaan dalam menangkap warna-warna yang ada, sehingga mereka akan sulit membedakan beberapa warna seperti merah, hijau, kuning dan biru.

2) Metode Colour Gradation : Pengujian menggunakan metode colour gradation dilakukan dengan cara menguji apakah peserta tes dapat mengenali perbedaan warna yang terdapat pada 6 buah pelat gambar colour gradation atau gradasi. Pelat gradasi warna yang digunakan berjumlah 6 buah dengan kombinasi warna yang masing-masing pelat memiliki 6 warna berbeda yang membentuk sebuah gradasi warna.

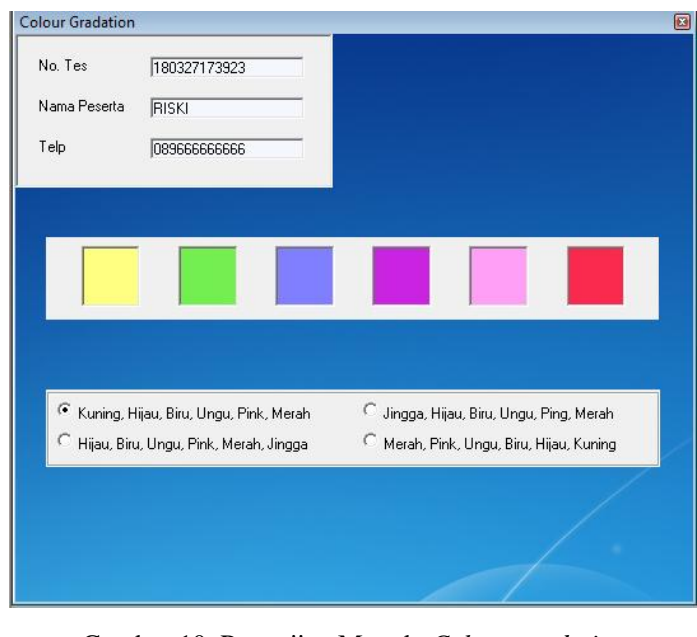

Gambar 10. Pengujian Metode Colour gradation

Pada gambar 10 dapat dilihat metode colour gradation yang digunakan pada aplikasi. Peserta tes akan melihat pelat gradasi warna yang terdiri dari beberapa kombinasi warna. Kombinasi warna inilah yang dijadikan filter pengujian dalam metode colour gradation. Hal tersebut karena peserta yang mengalami gejala kepekaan dalam menangkap warna-warna yang ada, sehingga mereka akan sulit membedakan beberapa 
warna-warna yang memiliki kemiripan seperti hijau dan kuning, biru dan ungu, merah dan pink, dan sebagainya.

3) Metode Farnsworth : Pengujian menggunakan metode Farnsworth dilakukan dengan cara menguji apakah peserta tes dapat mengenali perbedaan warna yang terdapat pada 13 buah pelat gambar Farnsworth. Pelat Farnsworth memiliki warna yang digunakan sebanyak 13 buah dengan kombinasi yang membentuk sebuah gradasi warna dengan tingkat kesulitan yang lebih tinggi dari pada metode colour gradation.

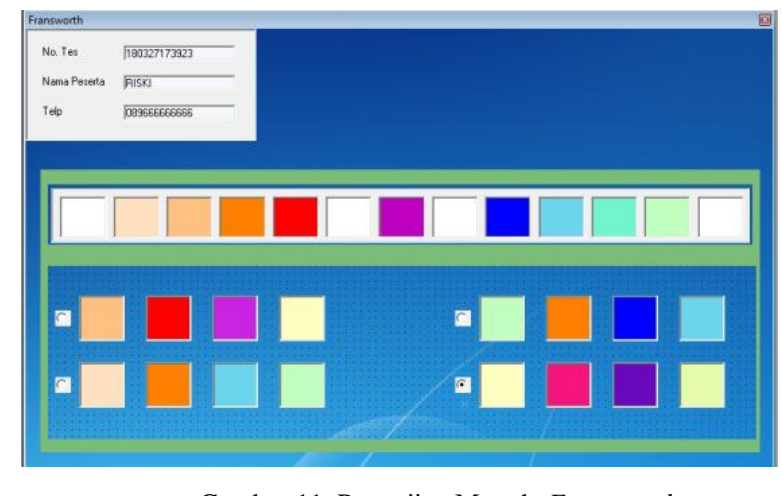

Gambar 11. Pengujian Metode Farnsworth

Pada gambar 11 dapat dilihat metode farnsworth yang digunakan pada aplikasi. Peserta tes akan melihat pelat farnsworth yang terdiri dari beberapa kombinasi warna yang membentuk sebuah gradasi sehingga mereka akan sulit membedakan warna-warna yang memiliki kemiripan seperti hijau dan kuning, biru dan ungu, merah dan ping, dan sebagainya. Sebagaimana pada metode colour gradation, metode farnsworth juga menggunakan gradasi warna dalam pengujiannya namun pada metode ini memiliki tingkat kesulitan yang lebih tinggi karena memiliki 13 kombinasi warna yang berbeda

4) Hasil Tes : Tes dilakukan dengan beberapa koresponden yang mengikuti tes tes pertama pasien diberikan soal dengan buku konvensional dan tes kedua pasien diberikan soal dari aplikasi tes buta warna dengan perolehan nilai pasien yang dapat dilihat pada tabel 2 :

TABEL II.

HASIL TES MANUAL DAN APLIKASI

\begin{tabular}{|c|l|c|l|c|c|}
\hline \multirow{2}{*}{ No } & \multirow{2}{*}{$\begin{array}{c}\text { Nama } \\
\text { Responden }\end{array}$} & \multicolumn{2}{|c|}{ Tes manual } & \multicolumn{2}{c|}{ Tes Aplikasi } \\
\cline { 3 - 6 } & Ishihara & Keterangan & Aplikasi & Keterangan \\
\hline 1. & Evan Susanto & 100 & Mata Normal & 90 & Mata Normal \\
\hline 2. & Fahrur Rozi & 70 & Mata Normal & 100 & Mata Normal \\
\hline 3. & Zulfikar I & 90 & Mata Normal & 100 & Mata Normal \\
\hline 4. & Eka Yudi & 90 & Mata Normal & 80 & Mata Normal \\
\hline 5. & Gatot S & 100 & Mata Normal & 90 & Mata Normal \\
\hline
\end{tabular}

Berdasarkan hasil tes tersebut diperoleh hasil nilai yang sedikit berbeda namun dengan hasil kategori keterangan kesehatan mata yang sama sehingga dapat disimpulkan aplikasi ini sudah memiliki hasil diagnosa yang sama dengan tes konvensional sehingga dapat dijadikan acuan sebagai pengganti tes buta warna konvensional, tes buta warna ini juga dalam pembuatannya dibantu dan dipandu oleh seorang dokter mata yang bernama dr. Mahyudi, Sp.M., M.Kes. menyimpulkan bahwa aplikasi tersebut memiliki metode yang sama dengan tes buta warna pada umumnya dan telah sesuai dengan sebagai acuan tes buta warna.

\section{KESIMPULAN DAN SARAN}

\section{A. Kesimpulan}

Berdasarkan hasil penelitian yang dilakukan, dapat disimpulkan:

Berdasarkan hasil dari percobaan aplikasi karakter soal menggunakan metode ishihara ditambah dengan soal metode pendukung yaitu colour gradation dan farnsworth hasil jawaban pasien dirangkum dan dihitung hasil penilaian diagnosa dari aplikasi memiliki hasil diagnosa yang sesuai dengan hasil dari tes konvensional sehingga disimpulkan antara tes dengan aplikasi dan konvensional itu sejalan.

\section{B. Saran}

Pada penelitian selanjutnya diharapkan agar metode yang digunakan lebih banyak sehingga akurasi dari aplikasi tersebut dapat semakin baik. Aplikasi juga dapat dikembangkan ke dalam versi mobile atau smartphone sehingga lebih praktis untuk digunakan.

\section{REFERENSI}

[1]. Utami. S., Seluk Beluk Buta Warna. Yogyakarta: Pustaka Baru Press, 2015.

[2]. Ganong, W. F., Buku Ajar Kedokteran, Edisi Dua Puluh. Jakarta: Buku Kedokteran EGC. 2003

[3]. Guyton. A., \& Hall, J. E., Buku Ajar Fisiologi Kedokteran, Edisi Sembilan. Jakarta: Buku Kedokteran EGC, 1997.

[4]. Handayani. E., Universitas Sumatera Utara. Gambaran Pengetahuan Mahasiswa/i Fakultas Kedokteran Universitas Sumatera Utara Stambuk 2008 - 2010 Mengenai Buta Warna, 2011.

[5]. Rokhim. A. N, Mengenal Tes Buta Warna. Surabaya: Rona Publishing, 2015.

[6]. (2010) Colour Blind Essentials. [Online] Avalaible: https://www.colour-blindness.com

[7]. (2019) Halodoc. [Online] Avalaible: https://www.halodoc.com/harus-tahu-inilah-7-fakta-pentingmengenai-buta-warna.

[8]. (2018) Dokter sehat [Online] Avalaible: https://doktersehat.com/buta-warna/.

(2017) Aladokter. [Online]. Available: https://www.alodokter.com/buta-warna

[10]. Murti, Hari \& Santi, “Aplikasi Pendiagnosa Kebutaan Warna dengan Menggunakan Pemrograman Borland Delphi," (2011).

[11]. Widianingsih. Ratri, "Aplikasi Tes Buta Warna dengan Metode Ishihara Berbasis Komputer,” 2010.

[12]. Hnt. Ahmad, "Rancang Bangun Sistem Informasi Laporan Keuangan Kecamatan Pontianak Utara Sesuai Dengan Standar Akuntansi Pemerintahan Berbasis Client-Server," Vol 3, No 2, 2015.

[13]. Yandika, "Perancangan Aplikasi Rencana Anggaran Biaya (RAB) Untuk Pengadaan Material Pemeliharaan Jalan," Vol 4, No 3, 2016. 
[14]. Hartanto Eri, "Perancangan Sistem Informasi Geografis Persebaran Dan Kondisi Lokasi Bangunan Gedung Berdasarkan Izin Mendirikan Bangunan (IMB) Kota Singkawang," Vol 4, No 3, 2016.

[15]. Purnama. Rangga Reza, "Rancang Bangun Sistem Pendukung Keputusan Pengelolaan Dana Bos Dengan Metode Analytical Hierarkhi Process (AHP)," Vol 3, No 2, 2015.

[16]. Zaid. M Abang "Sistem Pendukung Keputusan Pemilihan Mata Kuliah Pilihan Menggunakan Metode Analytic Hierarchy Process (Studi Kasus: Jurusan Teknik Elektro Fakultas Teknik Universitas Tanjungpura)," Sistem Pendukung Keputusan Pemilihan Mata Kuliah Pilihan Menggunakan Metode Analytic Hierarchy Process (Studi Kasus: Jurusan Teknik Elektro Fakultas Teknik Universitas Tanjungpura)," Vol 5, No 2, 2017.

[17]. Manik. Elizabeth Airani "Sistem Pendukung Keputusan Perbandingan Tingkat Pelanggaran Perlindungan Kekerasan pada Anak," Vol 3, No 1, 2015.

[18]. Irwansyah. Muhammad, "Sistem Informasi Repository Digital Beban Kerja Dosen," Vol 1, No 1, 2015.

[19]. J.Alcala ,"Keel Data Mining Software Tool Data Set Repository integration of algorithms and experimental analysis framework", 2010.

[20]. Anggraini.Abriana Recha, "Penerapan Data Mining Classification untuk Data Blogger Menggunakan Metode Nä̈ve Bayes," Vol 7, No 1, 2019. 